\title{
記念講演 要旨
}

\section{びまん性脳損傷の病態}

\author{
中沢 省三 \\ 日本医科大学脳神経外科学教室
}

\section{はじめに}

本学に脳神経外科学講座が開設されてから 20 余年の歳月が流れているが,この間の脳神経 外科学の進歩は凄ましく,約 5 年間を 1 つの単位としてめまぐるしい発展を遂げてきている. 開設当初の知識や技術はすべて塗り変えられたとみてよいであろう.

脳神経外科学には大別して 3 つの大きな診療・研究の領域がある.その第 1 の領域として 脳腫㿎をあげることができるが,この中の良性腫瘍の治療に関しては, CT を始めとする種々 の画像診断の発展と microsurgery の導入などにより，ほほ完成された感がある.しかし，悪 性グリオーマと転移性脳腫瘍は, 多くの補助療法や化学療法を駆使しても予後は極めて不良 で, あらゆる悪性腫瘍の治療の進歩からとり残された感がある.

われわれの教室では，開設早期から，これらの悪性脳腫瘍に対して制癌剤の局所注入療法 を考案し, 治療成績の向上に努め, 認められる成果をあげてきた。現在は, 更に補助療法と してインターフェロン療法を加えると共に, 種々の制癌剤の組み合わせによる化学療法（全 身投与), 放射線療法を併用しているが, 最近ではモノクローナル抗体を用いたミサイル療法 などの基礎的研究に取り組んでいる.いずれ遺伝子治療も導入されるであろう.

また，第 2 の領域である脳血管障害の治療法も飛躍的な進歩を遂げ，特にクモ膜下出血な ど出血性脳血管障害の手術手技の改善は, 過去の多くの不可能な治療を可能にした. しかし, この治療法もここ数年来は反省期に入っており,QOL を中心とした治療法の選択へと変わり つつある. 当教室が厚生省の依頼をうけ，厚生行政科学研究事業の一環としての「わが国の 遷延性意識障害患者（いわゆる植物症）の実態調査」を行ったところ, 植物症の原因疾患と して脳血管障害が全体の $70 \%$ を占め, そのほとんどが外科系施設で手術をうけた患者で，そ の発生率が年毎に急増していることが浮き彫りにされた。これらをふまえ, 現在脳動脈奇形 にはガンマナイフを用いた保存的療法が主流を占めるようになり, 出血性および閉塞性脳血 管障害に対する血管内手術療法が開拓されつつある.われわれもこの方面の手技や研究に積 極的な努力を重ねてきており, 今後の発展が期待される.

さらに第 3 の領域として頭部外傷をあげることができる．この分野も補助診断法の発展を 機に飛躍的な進歩を遂げてきている．特に動物実験を基盤にしてうち立てられたびまん性脳 損傷の概念が導入されてから，従来の頭部外傷に対する考え方が根本的に改められた感があ り, 今回はこの分野についてのわれわれの研究を中心に概説する. 


\section{1.びまん性脳損傷の概念の確立}

臨床的に，外傷性脳損傷をびまん性および局所性脳損傷 (diffuse and focal brain injuries： DBI and FBI 以下これに略す) に2大別する考え方が普及し始めてから 10 年余が経過して いる.しかし，まだすべての専門医に一律に DBI，FBI の概念が理解され認められているわ けではなく，その分類においても多くの問題点が指摘されている．この中の FBI とは，脳の 損傷が比較的限局していると考えられるもので，従来の頭部外傷の治療の主体をなした種々 の急性頭蓋内血腫がこれに入る.すなわち, 従来の頭部外傷の治療のほとんどがこの FBI の 概念の中でのみ行われてきたわけで, 甚だ片手落ちであったと云わざるを得ない.一方, DBI とは，上記のような頭蓋内占拠性病変がないにもかかわらず，広汎な脳の損傷を伴うと考え られる群を指す，損傷が極めて軽微に過ぎれば従来云われている脳振盪に終るが，意識障害 が持続し遷延すれば，病理学的なびまん性軸索損傷（diffuse axonal injuries : DAI 以下これ に略す）がその主体をなす。この他外傷後急速に進展する 1 側性または両側性の急性脳腫脹 も DBI の 1 つの型と見做されている.

\section{2. びまん性脳損傷の臨床と病理}

われわれの教室では, DBI の概念が普及する以前からこの問題に取り組み, 臨床像の解明 と病理学的な検討を行い, 本疾患に対しての本邦における指導的役割を果してきた。これは DBI の実験的研究のメッカであるペンシルバニア大学脳神経外科学教室の Prof. Langfitt や Prof. Gennarelli らと早くから学問的な交流があり, 彼らの研究に直接ふれる機会が多かっ たからである。

DBI は臨床的には古くからその存在が知られ, 特に交通外傷などの high velocity injury によくみられるもので, 重症例はかつては 1 次性脳幹部損傷と間違われていた。この損傷の 力学的発生機序は Holbourn の提唱した回転角加速度による剪断力 (shearing force) が主体 と考えられている，この剪断ひずみにより，脳表から脳深部にわたるびまん性の損傷が，主 として軸索の断裂という型で生じる．このため臨床的には受傷直後からの意識障害と神経症 状の出現を特徵とするが，CT，MRIによる補助診断が必須で，これによりまず FBI を否定 しなければならない.

DBI の臨床的な特徵をまとめると, (1)発症年齢層は比較的若年者男性 (20 歳代) に多く, (2)交通事故による受傷，特に high velocity injury を特徵とし，(3)外傷による受傷部位を特定 することが困難で，(4)頭蓋骨骨折を証明することが少なく，(5)受傷直後から何らかの意識障 害を特徵とする. 重症例の入院時の Glasgow Coma Scale は 7 以下の場合が多く, その予後 は極めて悪い．意識障害が 24 時間以上続き，かつ脳幹症状（眼症状など）を呈した症例の過 半数は死亡するが植物症に移行する.

剖検所見では, 脳梁部, 中脳背側部, 脳幹部, 脳室内などに小出血巣や脳挫傷を認め, 光 顕学的には大脳白質の広範な軸索の損傷を特徵とし，これらの病変は脳幹部にまで及び，軸 
索の断裂, 腫脹, axonal retraction ball の形成が広くみられる。こうした axonal damage の所見は受傷後 $2 \sim 3$ 週間で消失し, その後は Waller 氏変性に陥ってゆく.もちろん軽症に なるにつれて,これらの病理学的変化は少なくなり, 脳振盪例では変化は認め難くなる.脳 振盪軽症例では, 軸索な断裂までに至らず, 一時的な dysfunction に陥るものと思われる.

\section{3.びまん性脳損傷の CT, MRI による特徵}

$\mathrm{DBI}$ の診断の最大の根拠は, CT, MRI によって頭蓋内占拠性病変 $(\mathrm{FBI})$ を認めないこと が第 1 条件となるが, その他にもこれらの補助診断法は DB1 の多くの病態を視覚的に写し出 してくれる.特に MRI はこの病態の描写に優れており, われわれの検索によれば, DBI の軽 症 (脳振盪) から重症（軸索損傷）になるにつれて, 局所性脳浮腫 $\rightarrow$ 非出血性脳挫傷 $\rightarrow$ 出血 性脳挫傷の所見が進行性に出現してくる.これらの発現率は, MRI では脳振盪群で $50 \%$, 軸 索損傷群で $100 \%$ に達する.これに対し CT では脳振盪群での発現率は極めて低く, 軸索損傷 に出血を伴うと急に発現率は高くなる.すなわち, DBI の主体である DAI は, MRIにより確 実にその病態をとらえることができる.また, DBI のもう 1 つの型であるびまん性脳腫脹も， それが一側性であれ両側性であれ，CT, MRI で確実に診断することが可能である。

\section{4. びまん性脳損傷の代謝動態}

DBI の重症例は軸索や神経細胞を含めた脳実質の広範な損傷が予想されるため, FBI に比 ベて異なった代謝動態を示す。重症例における教室の研究では, 脳組織の損傷の程度を反映 するとされる血清 creatine phosphokinese brain type が対照群に比し明らかな高值を示し, また, 下垂体前葉ホルモンの 1 つである血漿 PRL も明らかに高值をとり, かつ TRH 負荷に よる反応が極めて悪いことなどが認められている.これらの変化は, 他の研究者による重症 脳損傷における血清 neuron specific enolase (NSE) 值の上昇や Serum-myelin-basic-protein 值の上昇などと相通ずる軸索や neuron の損傷の程度を反映するものであろう. 教室では現 在実験的 fluid percussion injury model を用い, 糖代謝, エネルギー代謝, heat shock protein, 脳温の研究などを行っている. 今後の治療法に期待が寄せられる.

一方, 重症 DBI の頭蓋内圧持続測定では, その $2 / 3$ が $20 \mathrm{mmHg}$ 以下であったが, 残り $1 / 3$ は $20 \mathrm{mmHg}$ 以上に上昇し,この中であらゆる治療に反応しなかったものは, 脳灌流圧が 0 と なり全例死亡した.これらは DBI による 2 次的脳腫脹が起ったものと理解される.

経時的聴性脳幹反応 $(\mathrm{ABR})$ は, 測定し得た重症 DBI 症例の $80 \% に \mathrm{I}-\mathrm{V}$ 波間の潜時の延 長, またはV波の消失を認めた. そして, 経過中に無反応となったものはすべて死亡してい る. その他内頸静脈血酸素飽和度 $\left(\mathrm{SJO}_{2}\right)$ やレーザードプラー法による脳血流 $(\mathrm{CBF})$ の測 定なども行われているが, $\mathrm{DBI}$ の重症例では, $\mathrm{SJO}_{2}$ が正常から若干高值を示しているのに, CBF は低い值を保っており, 脳血流に比して, 脳代謝が極端に低下した luxury perfusion の 状態を示す例のあることも見出されており，今後これらの動態が明らかにされるにつれて， 
治療への道が開けてくるものと思われる.

\section{5.びまん性脳損傷の治療}

DBI は軸索の損傷が主体なので通常脳圧は高值を示さず，もっぱら保存的療法に委ねられ る.しかし, 脳腫脹を伴った場合は脳圧方進に対する治療法（外減圧術, 脱水療法など）が 必要となる。

目下のところ軸索の損傷に対しての予防法も特殊な治療法もないので, 呼吸, 循環, 栄養 の管理によって 2 次的脳虚血や合併症の防止に努める. 軽症例の予後は概して良好で後遺症 も極めて少ないが, 重症例の予後は不良であり, 死亡するか植物状態への移行が多い.また, 従来いわれてきた脳幹部損傷（1 次性）も, 単独では存在せず, DAI 重症例の 1 つの型であ るとされている．また，最近の研究によれば，軸索の損傷は，受傷時瞬時に断裂するのでは なく, 6〜72 時間の経過の中で軸索の代謝障害 $\rightarrow$ 軸索腫脹をきたして漸次断裂されてくるこ とがわかってきているので，この間に新しい防止法や治療法の開発が期待できる.

\section{6. びまん性脳損傷の概念の重要性と新しい分類}

実際の診療の場においては, DBI とFBI がそれぞれ独立して発生することは極めて少な く, 何らかの形で種々の程度に 2 者が混在して発生する場合がほとんどである. 頭部外傷急 性期の診療に当って最も大切なことは, 両者がどの程度合併しているかを常に考慮しながら 治療と予後の判定を行ってゆくことで, そのためには受傷直後からの意識障害の有無, 程度 や神経所見の推移と CT, MRI の継時的検査が極めて大切となる. 特に FBI の手術や治療に 際して, DBI の合併が患者の予後に大きくかかわってくることを理解しておく必要がある.

Gennarelli は, concussion を含めたすべての DBI の主体を, 軸索損傷という病理学的用語 でとらえ,これをそのまま臨床診断に用いたため多くの混乱を生じたが, 筆者はこれらの病 理学的用語を廃し, さらにこれに脳腫脹を加えて以下のように分類し診断・治療を行ってい る.

びまん性脳損傷の分類：1）軽症びまん性脳損傷；受傷後より一過性（6 時間以内）の意識 障害や記憶障害がみられるもの, または一時的な神経症状が加わったもの, 2) 中等症びまん 性脳損傷：受傷直後より意識障害が 6 時間以上持続するもの, または長時間持続する神経症 状が加わったもの，3）重症びまん性脳損傷：受傷直後より意識障害が 24 時間以上持続し, かつ脳幹症状を合併するもの, 4) びまん性脳腫脹；受傷直後か受傷一定時間後, CT や MRI 上一側性または両側性の脳腫脹をきたし, 意識障害や神経症状を呈するもの. 


\section{主たる研究業績}

\section{I 欧文原著}

1. Acute traumatic intraventricular hemorrhage in children

2. Thyrotropin-releasing hormone provocative release of prolactin and thyrotropin in acute head injury

3. Evaluation of postoperative intratumoral injection of bleomycin for craniopharyngioma in children

4. Prognostic significance of serum $\alpha_{1}$-acid glycoprotein in patients with glioblastoma multiforme

5. A model of brain abscess: septic homologous blood clot emboli in rats

6. Selective change of blood flow in experimental brain tumor with induced hypertension

7. Metabolic studies of the edematous cerebral cortex of the pyrithiamine-treated thiaminedeficient rat

8. Induction of lymphokine-activated killer cells from rat thymocytes using recombinant human interleuken-2

9. Suppression of splenic natural killer cell activity in rats with brain tumors

10. The role of orygen free radicals and iron in the genesis of traumatic brain injury and brain edema

11. Significance of magnetic resonance imaging in acute head injury

12. Experimental radioimmunotherapy of a xenografted human glioma using ${ }^{131}$ I-labeled monoclonal antibody to epidermal growth factor receptor

13. Suppression of 9L gliosarcoma growth by copper depletion with copper-deficient diet and D. penicillamine

14. Zinc enhances kainate neurotoxicity in the rat brain

15. Human monoclonal antibody-drug conjugates in the experimental treatment of malignant gliomas - Studies in vitro and in vivo- $\begin{array}{lllll}\text { Child's. Nerv. } & 1 & 18 & 1985\end{array}$

Syst.

Neurosurgery. $\quad 16 \quad 791, \quad 1985$

$\begin{array}{llll}\text { J. Neurosurg. } & 62 & 120 & 1985\end{array}$

$\begin{array}{llll}\text { J. Neurol. } & 48 & 835 & 1985\end{array}$

Neurosurg.

Psychiat.

$\begin{array}{llll}\text { J. Neurosurg. } & 64 & 125 & 1986\end{array}$

$\begin{array}{llll}\text { Surg. Neurol. } & 27 & 433 & 1987\end{array}$

$\begin{array}{llll}\text { Brain Res. } & 441 & 202 & 1988\end{array}$

$\begin{array}{lllll}\text { Cancer Im- } & 27 & 13 & 1988\end{array}$

munol. Im.

munother.

Neurosurgery

23

1988

Adv. Neuro

2

trauma Res.

J. Trauma

31

351

1991

Neurol. Med.

33

610

1993

Chir.(Tokyo)

J. Neuro-

Oncology

17

91

1993

Neurol. Res.

15

113

1993

Neurol. Med.

34

279

1994

\section{II 和文原著}

1. 生化学の立場からみた脳浮腫の動態

2. Craniopharyngioma の内分泌および水分・電解質 代謝異常について

3. 実験脳腫瘍における Adriamycin 局所注入療法の 病理学的研究

4. 悪性腫㾤に対する新しい治療法の試み 1. Bleomycin 局所注入療法について

\begin{tabular}{|c|c|c|c|c|c|}
\hline 災 & 害 & 医 & 学 & 16 & 175 \\
\hline & 神 & 外 & 科 & 2 & 221 \\
\hline & 神 & 外 & 科 & 9 & 799 \\
\hline & 神 & 外 & 科 & 9 & 1487 \\
\hline
\end{tabular}


5. 悪性脳腫瘍に対する新しい治療法の試み 2. Adriamycin 局所注入療法について

6. 脳浮腫の生化学

7. 腫瘍性脳浮腫の病態分析一Contrast-enhanced CT scan と dynamic CT scan を中心としてー

8. わが国の植物状態患者の動態

9. 急性期頭部外傷の代謝変動一血中 norepinephrine 值を中心として一

10. 植物状態患者の疫学的研究

11. 頭部外傷急性期に打ける血清 creatine phosphokinese isoenzyme 值の経時的変動と予後

12. 軽度意識障害から急激に悪化する頭部外傷例の CT 像一Talk and deteriorate

13. 洒漫性脳損傷一治療と結果一

14. 急性期頭部外傷における免疫能の変動一急性相反応 蛋白, 補体活性を中心として一

15 Diffuse axonal injury 5 剖検例の臨床病理学的検 討

16. 植物状態患者の現況と問題点

17.びまん性軸索損傷の臨床と病理

18. 高齢者の脳腫瘍および頭部外傷の特徵

19. Severe diffuse axonal injury (Gennarell) の診断 および病態像

20. 重症脳障害における頭蓋内圧と脳循環動態

21. 皮下移植脳腫場モデルにおける銅代謝と銅キレート 療法の可能性

22. Delayed traumatic intracerebral hematoma

23. Diffuse axonal injury

24. Battered child syndrome を呈した 8 剖検例の神経 病理学的研究

25. 複数の autocrine loop 遮断によるヒト悪性 glioma 細胞の増殖制御効果について
脳 神 外 科 $\quad 11 \quad 821 \quad 1983$

神 研の 進歩 $\quad 28 \quad 589 \quad 1984$

脳 神 経 $\quad 36 \quad 1055 \quad 1984$

医のあゆみ $135 \quad 5561985$

$\begin{array}{lllll}\text { 脳 神 経 } & 38 & 789 & 1986\end{array}$

日本医事新報 3266号 $26 \quad 1986$

Neurol. Med. $27 \quad 90 \quad 1987$

Chir.

CT 研 究 944968

N eurosur- $\quad 6 \quad 27 \quad 1987$ geons

$\begin{array}{lllll}\text { 脸 神 経 } & 39 & 1111 & 1987\end{array}$

脳 神 外科 $16 \quad 467 \quad 1988$

医のあゆみ $150416 \quad 1989$

脸 神 外科 $17 \quad 247 \quad 1989$

$\begin{array}{lllll}\text { 綜 合 臨 } & 38 & 2461 & 1989\end{array}$

$\begin{array}{lllll}\text { 神 経 外 傷 } & 12 & 3 & 1989\end{array}$

神経の進歩 $36 \quad 271 \quad 1992$

医のあゆみ 1654951993

救 急 医 学 $\quad 17 \quad 1064 \quad 1993$

救 急 医 学 $17 \quad 1045 \quad 1993$

脸 神 外科 $22 \quad 23 \quad 1994$

$\begin{array}{lllll}\text { 脳 神 経 } & 46 & 159 & 1994\end{array}$

\section{III 総 説}

1. 脳浮腫の治療対策

2. 外傷性水頭症

3. 頭蓋内圧方進, 脳浮腫の面から

4. 術後脳浮腫

5. 術中, 術後における脳浮腫の合併とその対策

6. 脳神経外科領域における最近の進歩と動向

7. 脳血管障害の外科的治療の現況

8. 脳脊髄外傷をめぐる問題点（植物状態や患者の背景 等, 社会的な問題も含めて)

9. 激症型くも膜下出血（DOA，near DOA）の病態と 早期管理の重要性
日医師 会誌

綜 合 臨 床

脳神経

外

外科診療

日 医大誌

日 医大誌

Brain nursing

日本臨床

51

1993 
10. 老年者に多い䋃腫瘍の症状と診断一Metastatic 老化と疾 患 $\quad 7 \quad 748 \quad 1994$ brain tumor (転移性脳腫瘍) -

\section{IV 著 書}

1.「分担」外科診療二頁の秘決：頭部外傷急性期の診療

金 原 出版 1977

2.「分担」救急プライマリケアハンドブック：脳ヘルニア：検眼鏡

克誠堂 1980

3. 「分担」新臨床外科学 : 頭蓋内圧元進・脳浮腫・脳嵌入

医 学 書院 1981

4.「分担」看護のための臨床医学大系：頭部外傷

情報開発研究所 1983

5.「共著」外傷の救急治療：頭部外傷

南山堂 1988

6.「共著」膇神経外科看護の知識と実際：救急室における看護の役割

メヂィカ出版 1989

7.「分担」外傷救急：頭部外傷

8.「分担」脳神経外科疾患の手術と適応II ：びまん性脳損傷

メ ジカル ル 1989

9.「分担」最新・救急治療マニュアル：頭部外傷

朝 倉 書 店 1990

10. 監修・共著」脳神経外科

メヂイカ出版 1991

医学評論社 1993 


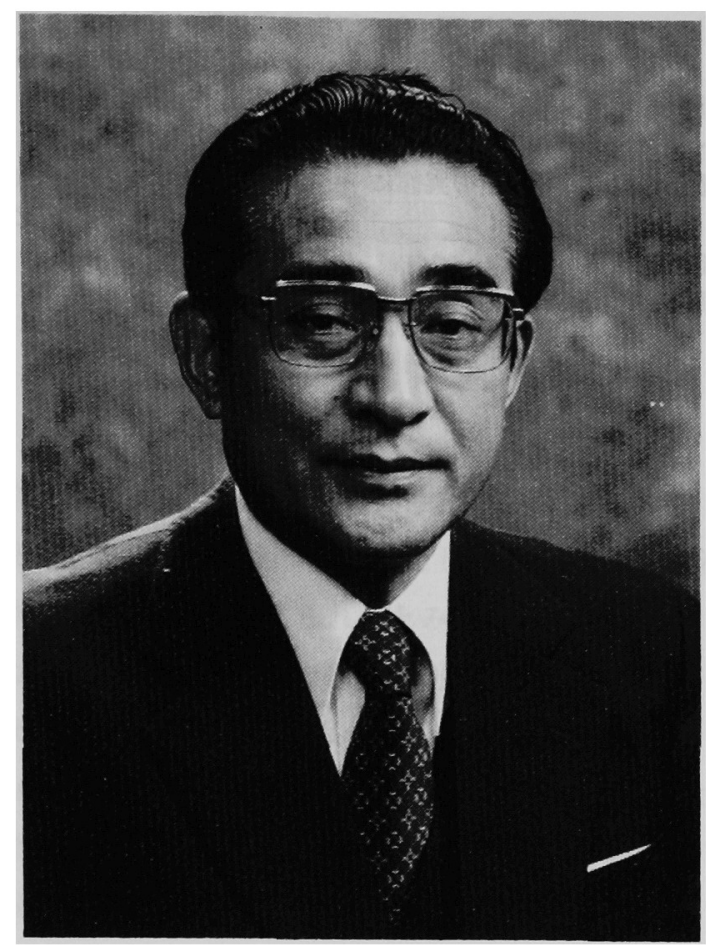

\section{中沢 省三教授}

\section{略 歴}

\begin{tabular}{|c|c|c|c|}
\hline 1929 年 9 月 & 新潟市に生れる & 1967 年 4 月 & 社会保険診療報酬請求書審査委員 \\
\hline 1945 年 3 月 & $\begin{array}{l}\text { 官立新潟高等学校理科第一学年修 } \\
\text { (学制改革) }\end{array}$ & 1968 年10月 & 脳神経外科専門医認定（第225号） \\
\hline 1951 年 3 月 & 新潟大学医学部プレメヂカル卒業 & 1969 年10月 & 新潟大学医学部講師 \\
\hline 1955 年 3 月 & 新潟大学医学部卒業 & 1971 年 4 月 & 新潟大学歯学部講師併任 \\
\hline 1956 年 8 月 & 医師国家試験合格（第160269号） & 1972 年 5 月 & 日本医科大学脳神経外科学教授 \\
\hline 1960 年 3 月 & $\begin{array}{l}\text { 新潟大学医学部大学院医学研究科 } \\
\text { (胛神経外科学) 修了 (学位記) }\end{array}$ & $\begin{array}{l}1977 \text { 年 } 4 \text { 月 } \\
1983 \text { 年 } 1 \text { 月 }\end{array}$ & $\begin{array}{l}\text { 東京都医師会学術委員 } \\
\text { 日本医科大学研究委員会委員長 }\end{array}$ \\
\hline 1961 年 7 月 & 新潟大学医学部助手脳神経外科学 & 1986 年 7 月 & 新潟大学医学部学士会本部幹事 \\
\hline 1964 年 7 月 & $\begin{array}{l}\text { Montreal Neurological Institute, } \\
\text { Canada 留学 (Neurosurgical Resi- } \\
\text { dent and Research Fellow) }\end{array}$ & $\begin{array}{l}1988 \text { 年12月 } \\
1989 \text { 年 } 4 \text { 月 } \\
1989 \text { 年 } 4 \text { 月 }\end{array}$ & $\begin{array}{l}\text { 臨床実習委員会委員長 } \\
\text { 日本医科大学教育委員会委員長 } \\
\text { 私立医科大学協会卒前医学教育 }\end{array}$ \\
\hline 1966 年12月 & $\begin{array}{l}\text { The Johns Hopkins Hospital 脳 } \\
\text { 神経外科学教室, U.S.A. 留学 } \\
\text { (Research Fellow) }\end{array}$ & 1992 年10月 & 中国沈阳医学院名誉教授 \\
\hline
\end{tabular}

学会・光の他

日本膇神経外科学会 評議員 日本神経学会 評議員
汎太平洋外科系学会日本支部会 理事長 汎太平洋外科系学会本部 幹事 
日本脳卒中学会 評議員

日本救急医学会 評議員

日本脳循環代謝学会 評議員

日本失語症学会 評議員・役員

厚生行政科学研究事業「遷延性意

関する研究」(厚生省, 班長)

学術審議会専門委員（文部省, 委員)

臨時脳死および臓器移植調査会専門委員（内閣総理大
臣諮問機関，委員）

Pan-Pacific Surgical Association Japan Chapter 7th

Congress. President

第16回日本神経外傷研究会 会長

第 4 回意識障害の治療研究会 会長

第 1 回植物症·尊厳死·脳死に関するシンポジウム 会 長 